\title{
Geology of Heron Island and Adjacent Reefs, Great Barrier Reef, Australia
}

\author{
School of Earth Science, University of Queensland, Brisbane, QLD 4072, Australia.E-mail: j.jell@bigpond.com; g.webb@uq.edu.au
}

Heron Island has been the focal point for research on the southern Great Barrier Reef Province for the last 80 years. Heron Reef is an excellent example of a lagoonal platform reef with a sand cay developed on its leeward end, displaying typical reef morphological, sedimentological and ecological zonations allowing comparison of their windward and leeward development. Limited subsurface data indicate that the total reef section is only $150 \mathrm{~m}$ thick, consisting of stacked limestone packages, with a gently eastward sloping solution disconformity delineating the base of c. $15 \mathrm{~m}$ of Holocene reef growth. Holocene reef growth does not appear to fit the "classical" model, with evidence of much progradation on the windward margin relative to the associated leeward margin. Large dredged blocks of reefal material provide new data on the abundance of in situ framework in much of the reef and the importance of microbialite in the unification process.

\section{Introduction}

Although Heron Reef is one of the most thoroughly studied modern coral reefs, sparse subsurface data suggest that it has much to teach us about late Quaternary reef development. The geomorphology of modern coral reefs reflects their evolution through Holocene sea-level rise. Various reef growth models have been proposed but variable settings (tectonics, tidal range, wave energy, storm activity, etc.) suggest potentially very different histories in different regions (e.g., Montaggioni, 2005; Montaggioni and Braithwaite, 2009). Although reefs are known to contain abundant sand and rubble, generally more or less enclosed within a 'framework' composed of in situ coral facies (e.g., Davies and Hopley, 1983), the degree to which in situ reef framework or reef rubble dominates reefs is controversial (e.g., Hubbard et al., 1990; Blanchon et al., 1997; Riegl, 2001). Unfortunately, most of what is known about Holocene reef evolution results from analysis and dating of relatively few drill cores (e.g., Hopley et al., 2007; Montaggioni and Braithwaite, 2009). Also, cores commonly target a particular facies within a reef, thus not allowing the lateral evolution of reef facies through sea-level rise to be determined (Hopley et al., 2007). Additionally, differentiating in situ coral framework and larger coral rubble in cores combined with general poor core recovery complicates the interpretation of reef cores (Hubbard et al., 2001).
Where multiple cores have been recovered from a single reef, growth models can be constructed. The reef growth model of Marshall and Davies (1982) suggests that following Pleistocene substrate inundation c. $8 \mathrm{ka}$, high-energy coral head facies and lower energy branching coral facies aggraded on the windward and leeward sides, respectively, with both initially lagging behind sea-level rise and the windward facies attaining modern sea-level sooner than the leeward after sea-level began to stabilise. Once sea-level was attained on the windward margin, progradation was directed primarily towards the backreef/lee. However, Hopley et al. (2007) noted from sparse data, that many GBR reefs evolved differently. Heron Reef affords observations of reef framework in large $(\mathrm{m}+)$ blocks dredged from the reef flat on the western end during enlargement of the boat harbor in 1988. These blocks provide good examples of the in situ coral framework. This paper proposes to place the Heron Reef framework and limited coring data in the context of regional geology of the southern Great Barrier Reef Province (GBRP).

\section{Regional Setting}

Heron Reef, in the southern GBRP had its geology outlined by Jell and Flood (1978) and the origin and evolution of the GBR have been reviewed by Davies (2011). The GBRP includes eastern Queensland's continental shelf that has been occupied or influenced by reefs and reef-derived sediments at any time since the initiation of reef growth. It represents the western margin of the Northeast Australian Carbonate Platform System, which also includes the reef provinces of the Gulf of Papua and the Eastern, Queensland, and Marion plateaus (Davies et al., 1988; Figure 1). The offshore plateaus and intervening troughs appear to be modified and subsided continental crust that originated from late Cretaceous-Paleogene rifting of the northeastern Australian Plate (Symonds et al., 1983).

At 2,300 km long, from Bramble and Anchor cays in the Gulf of Papua (latitude $9^{\circ} 15^{\prime} \mathrm{S}$ ) to $\mathrm{S}$ of Lady Elliot Island (latitude $24^{\circ} 10^{\prime} \mathrm{S}$ ) and covering $265,000 \mathrm{~km}^{2}$, the GBRP is the largest reefal and carbonate-siliclastic shelf system in the present oceans, and is comparable in size to some of the large carbonate platforms in the geological record.

The continental shelf is mostly a shallow $(0-90 \mathrm{~m}$, average $40 \mathrm{~m})$, partially rimmed, high-energy platform, sloping gently $(<1-$ $4 \mathrm{~m} / \mathrm{km}$ ) from the coast to the shelf edge and deepening southward. Apart from the latter and the $\mathrm{N}$ being wetter than the $\mathrm{S}$, there is little latitudinal variation. It is narrowest off Cooktown broadening to the $\mathrm{N}$ across Torres Strait into the Gulf of Papua and to the S off Broad Sound where the reefs occupy only mid to outer shelf areas. The shelf narrows considerably at its extreme southern margin where it is embayed by the Capricorn Channel. Throughout the length of the 


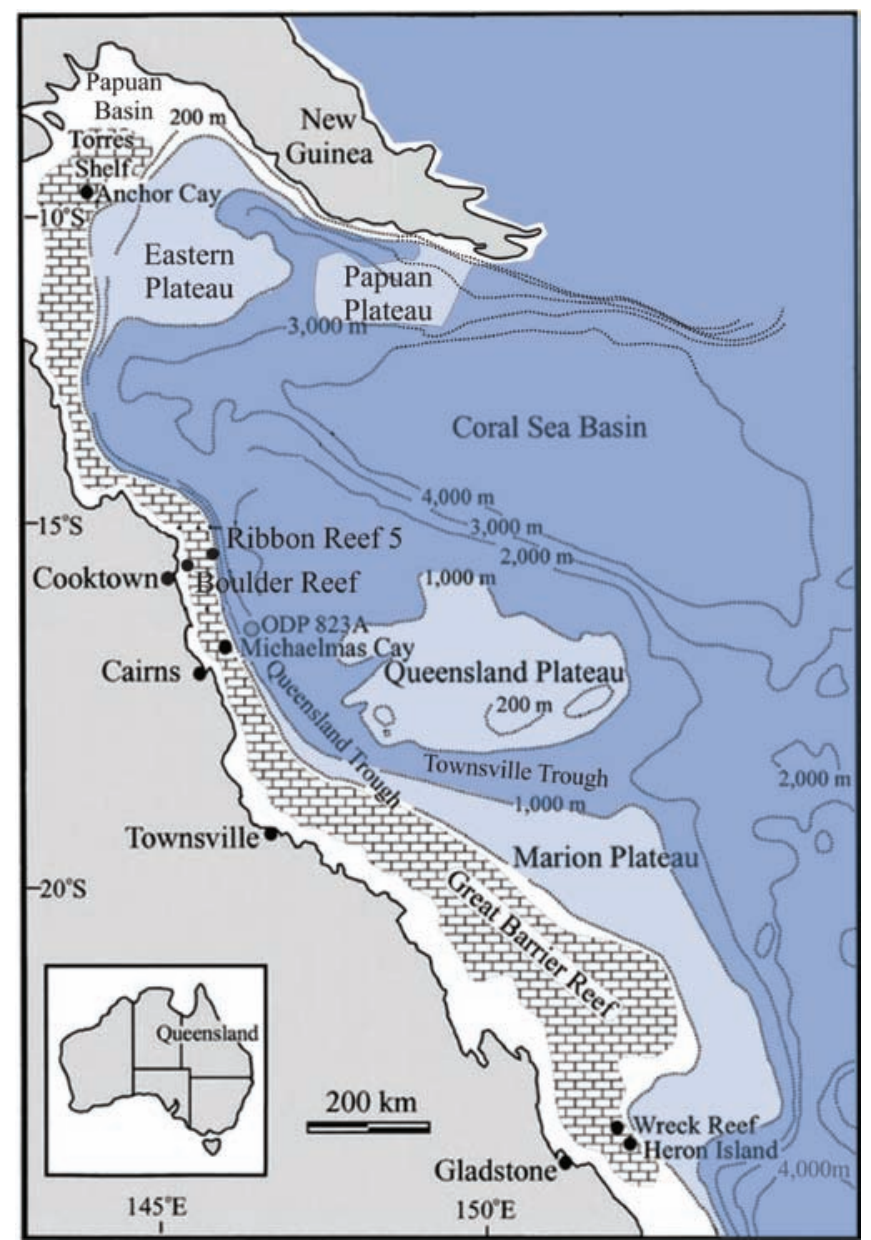

Figure 1 Location Great Barrier Reef within the Northeast Australian Carbonate Platform System showing the boreholes referred to in the text (after Braithwaite et al., 2004).

GBR there is a noticeable cross-shelf regional variation influenced primarily by wave energy and water quality.

Approximately 3,500 individual reefs occupy c. $25,000 \mathrm{~km}^{2}$ within the GBRP, less than $10 \%$ of the Provence. More than $86 \%$ of the reefs occur in a $25-65 \mathrm{~km}$-wide band along the eastern margin of the shelf. Maxwell (1969) referred to this zone of maximum reef development as the Reef Zone, which is separated from the Nearshore Zone by what is commonly referred to as the Shelf Lagoon. Hopley et al. (2007) provided detailed spatial data of the reefs for the Great Barrier Reef Marine Park based on available bathymetric surveys and satellite imagery.

Heron Reef at $23^{\circ} 27^{\prime} \mathrm{S}, 151^{\circ} 55^{\prime} \mathrm{E}$ is one of the Capricorn Group, which with the Bunker Group, Lady Elliott Reef ( $\left.24^{\circ} 07^{\prime} \mathrm{S}\right)$ and four northern shoals comprise the southernmost GBRP (Figure 2). Fourteen cays occur on 12 of the reefs with leeward sand cays more common than windward rubble cays. The reefs occur on the mid to outer shelf $80 \mathrm{~km}$ offshore. Water depths are 35-60 $\mathrm{m}$ and the reefs are 10$20 \mathrm{~km} \mathrm{~W}$ of the incised continental shelf edge (100 m isobath) in a zone of pure carbonate sediment (Maiklem, 1970). The continental slope is gentle and terraced with algal buildups at depths of 80 to $120 \mathrm{~m}$ (Davies et al., 2004). No drowned reefs have been reported from the continental edge in this region, although apparently in situ reef material was reported from the continental slope at $175 \mathrm{~m}$ (Veeh and Veevers, 1970; Yokoyama, et al., 2006) and drowned coral reefs occur farther N (Beaman et al., 2008; Abbey et al., 2011). The reef zone is separated from the terrigenous sediment-dominated inner shelf, by the Curtis Channel. Reefs are aligned on intersecting lineaments. The Bunker High extends $125 \mathrm{~km}$ from Lady Elliot Reef to North Reef. The other highs trend SW perpendicular to the shelf edge and parallel to prominent bathymetric trends in deeper water, with one line extending from Sykes Reef to Polmaise Reef $(50 \mathrm{~km})$ and another, shorter line, extending from Broomfield Reef to Northwest Reef.

The sea floor between reefs is flat or nearly so, except where reefs are close together with the bottom rough and commonly steep. Reef slopes in the channel between Heron and Wistari reefs are up to $45^{\circ}$. In general, leeward reef slopes are gentler than windward. Shoal areas connect many of the reefs, the most prominent being between Sykes and Heron reefs and the Isbell Shoal, connecting Northwest, Wilson and Broomfield reefs. In both cases the shoals rise from the shelf floor to $-15 \mathrm{~m}$. Prominent surfaces and terraces occur around the slopes of Heron, Erskine, Masthead, Polmaise, Wistari, Sykes, Wreck and Tryon reefs at -5 to $-7 \mathrm{~m}$, with an additional prominent $-15 \mathrm{~m}$ surface around Heron, Sykes, Lamont and Fitzroy reefs.

\section{Geological framework}

Basement of the GBRP is part of the Tasman Fold Belt, which forms the tectonic framework of eastern Queensland. Its history dates from the Ordovician and is represented by a series of NNW trending fault-bounded basins and highs. In the Mesozoic, intra-cratonic downwarps developed across the present coastline, such as the Maryborough Basin containing late Triassic-early Cretaceous clastic and some volcanic rocks deposited in continental to paralic and occasional shallow marine environments.

The present structure of the southern GBRP was shaped by continental break-up and rifting in the Late Cretaceous-Paleocene with the development of the Capricorn Basin between the western Bunker High above the Maryborough Basin and the Swains Reef High to the E (Maxwell, 1968). Rifting was initially associated with the spreading of the Tasman Sea to the SE, and then Palaeocene spreading of the Coral Sea Basin. Spreading terminated by the end of the Palaeocene-early Eocene and most subsequent movement has been vertical. Accompanying this spreading was the uplift of the adjacent mainland together with widespread Cenozoic volcanic activity.

The Cenozoic of the GBRP is represented along its central part by five depositional packages of sediment: (1) A thin syn-rift sequence of ?late Cretaceous-Paleocene, mainly continental to marginal marine, alluvial deposits; (2) Paleocene-Late Eocene marine onlap sequence, transgressive at its base but becoming open marine in its upper part, formed during continued cooling and subsidence; (3) A sequence of progradational-recessive phases of Late Oligocene, late Miocene, and late Pliocene-early Pleistocene age with progradation of fluviatile and wave-dominated shelf-margin deltaic sedimentation, and regressive phases of marine onlap facies; (4) A shelf aggradation/ progradation phase of Pleistocene age representing sea-level fluctuation, concurrent subsidence and deposition, becoming more marine in its upper section; (5) Late Pleistocene-Holocene reef development with pro-delta sediments on the inner shelf (Symonds, et al. 1983).

Until a few decades ago the GBR was widely considered to be millions of years old, even Miocene. However, Marshall (1983) and Symonds et al. (1983) suggested that it may be no older than 


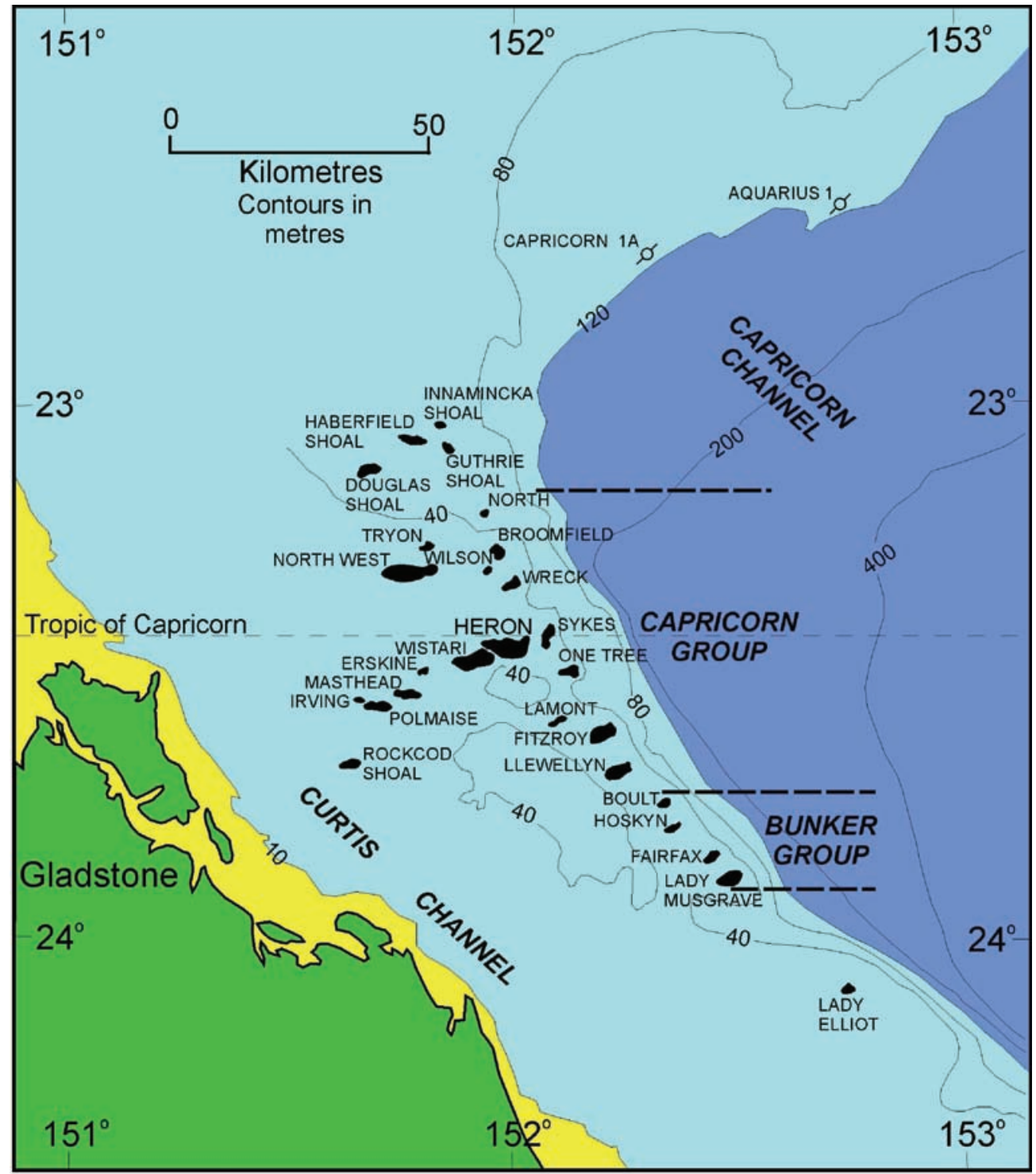

Figure 2 Map of the reefs of the southernmost Great Barrier Reef showing position of Heron Reef. separated by unconformities associated with glacial lowstands (see Braithwaite and Montaggioni, 2009). Flood (1993) recognised five solution unconformities within the Heron bore reefal sequence and it is assumed that latest Pleistocene aggradational reef facies of the southern GBR reefs consist of stacked highstand reef packages separated by unconformities associated with intervening lowstands.

\section{Prevailing physical conditions}

Maxwell (1968) and Hopley (1982) summarised the hydrology, climate and weather of the GBRP and Wolanski (1994) reviewed its oceanography and hydrodynamics. Maiklem (1968), Brandon (1973) and Marshall (1977) provided general details for the Capricorn Group. The Commonwealth Bureau of Meteorology, has recorded data since 1963 from weather stations on Heron Island, North Reef and Lady Elliot Island.

The climate is subtropical, with distinct summer and winter with monthly average maximums of 21.5$30^{\circ} \mathrm{C}$ and minimums of $16.5-24.2^{\circ} \mathrm{C}$. Sea surface temperature averages $20^{\circ} \mathrm{C}$ in winter and $27-28^{\circ} \mathrm{C}$ in summer. Rainfall averages $1,028 \mathrm{~mm} /$ year spread throughout the year with February to June the wettest months. The prevailing wind is the South East Trade, which blows for

Pleistocene. Seismic data and sediment cores from the continental slope suggested that the reef may have initiated as late as c. $500 \mathrm{ka}$ (Davies and Peerdeman, 1998). However, 'deep' cores from the GBR itself (Ribbon Reef 5 and Boulder Reef) constrained initiation of the central GBR to 452-365 ka (see Braithwaite et al., 2004). Those dates were questioned by Dubois et al. (2008) who suggested an age of initiation for southern central GBR at 670-560 ka on the basis of sediment cores from the Marion Plateau.

A core from Heron Reef in 1937 reached a total depth of c. $220 \mathrm{~m}$ including reef limestone to $156 \mathrm{~m}$ (Richards and Hill, 1942). Unfortunately, recovery was poor and the remains of the core are unlabelled rubble; no reliable dates were recovered. Hence, the age of initiation of the southernmost part of the GBRP remains unconstrained. Davies (1974) recognized the Pleistocene-Holocene boundary at c.15-20 m depth. The broad shoal that supports both Heron and Sykes reefs rises to c. $15 \mathrm{~m}$ depth (Jell and Flood, 1978), dipping slightly eastward, suggesting that both reefs represent Holocene growth on the same older Pleistocene reef basement. Ribbon Reef 5 core, in the northern GBR, suggests four to six packages of reef growth in the upper c. $96 \mathrm{~m}$ with the upper four successions approximately $70 \%$ of the year with a mean velocity of $12-18 \mathrm{~km} / \mathrm{hr}$ but with velocities greater than $36 \mathrm{~km} / \mathrm{hr}$ not uncommon. The summer months experience calms or NE-NNW winds and occasional cyclones. During winter, strong westerlies develop for short periods. Cyclones with winds up to $180 \mathrm{~km} / \mathrm{hr}$ superimpose their effects over the trade winds and significantly influence reef morphology (Flood and Jell, 1977).

The dominant South East Trades induce westward reef surface drift, but their velocities are generally low and their effect strongly affected by tidal current oscillation. Around Heron Island, the tidal range for spring tides is $2-3.3 \mathrm{~m}$ and for neaps $0.8-1.6 \mathrm{~m}$. On the outer shelf the flood tide sets $\mathrm{W}$ and the ebb E producing strong currents through the Capricorn reefs; currents in the channel between Heron and Wistari reefs can reach $7.5 \mathrm{~km} / \mathrm{hr}$. As the tide falls on the reef top, drainage is crudely radial until the rim becomes exposed when water flows through any gaps in the rim which are mainly leeward. The lagoons experience slack water for several hours during each tidal cycle. Thus shelf waters are replaced twice daily with oceanic waters. Two surface oceanic currents influence the region: the Sflowing East Australian Current, which flows parallel to, and only 
slightly impinges on, the shelf; and a northerly current during spring and into summer, which circulates water around the reefs.

Ocean swells of 1-3 m predominate from the ESE. Waves breaking on the reef may exceed $2 \mathrm{~m}$ and they refract around the reef producing lateral transport of sediment from windward to leeward. Sediment is deposited and may accumulate where wave sets converge (e.g., sand cays). Even at low tide with the reef top waters isolated from the ocean swell and waves, the wind shear over the shallow waters is sufficient to agitate sand-sized particles and to keep silt-sized particles in suspension.

\section{Reef types}

Fairbridge (1950), Maxwell (1968), Hopley, (1982), and Hopley et al. (2007) described three major reef types: (1) Linear or Ribbon reefs that grow along the shelf edge and only grow landward because water depths increase too rapidly on the continental slope; (2) Platform reefs that rise from the shelf floor and grow in any direction depending on the hydrological regime; and (3) Fringing reefs that grow seaward away from land or continental islands.

The reefs of the Capricorn-Bunker groups are platform reefs. Hopley (1982) recognised six stages of platform reef development, and apart from the submerged reefal shoals, all the southern reefs are mature or senile (i.e., lagoonal or planar). Their size and shape depend on that of their underlying foundation or 'antecedent platform'. They vary in maximum dimension $1-11 \mathrm{~km}$ with corresponding surface areas of c. $1-40 \mathrm{~km}^{2}$. Reefs with diameters $<3 \mathrm{~km}$ are all planar, as reef growth from their perimeter coalesces. Larger reefs trend from: a) deep lagoons with widely spaced, large isolated patch reefs; through b) shallow lagoons with numerous isolated patch reefs; through c) very shallow lagoons with reticulate patch reefs; to d) planar reefs without lagoons (e.g., westward Fitzroy-Heron-Wistari-Masthead). This progression primarily represents stages of lagoon infilling by reef detritus, and may depend on topography and depth of the antecedent platform, subsidence of the foundation, rate of reef growth or production rate of detritus. Subsurface data are too limited to assess this. The other factor influencing reef form is the hydrological regime, differentiating reefs on the relative development of windward and leeward features.

Heron Reef (Figure 3) is a moderate sized $(9.5 \times 4.5 \mathrm{~km})$, lagoonal, platform reef with a vegetated sand cay $(800 \times 300$ $\mathrm{m})$ on its leeward end. The Pleistocene surface on which the reef grew was 10-20 $\mathrm{m}$ (bmlw) as identified by refraction profiles adjacent to the island (Harvey, 1986), reflection seismic profiling (Smith et al., 1998) and the solution unconformity in the Heron Island bore. The unconformity dips $0.03^{\circ}$ to the $\mathrm{E}$ at c. $14 \mathrm{~m}$ (bmlw) and can be traced across the intervening shoal into Sykes Reef where it is slightly higher. The Heron lagoon is 3-3.5 m deep and has numerous patch reefs. Heron reef has a well developed windward margin broken only in the SE by a narrow channel, and a less well developed leeward margin indented and breached in several places such as at Blue Pools NE of the cay.

\section{Reef morphology}

Maxwell (1968) and Hopley (1982) outlined variation in GBRP reef morphology, showing the inter-relationship between morphological, ecological and sedimentological zones that parallel the line of intersection of the reefal mass and the water surface at low tide. Maiklem's (1968) zonation of Capricorn Group reefs was followed by Jell and Flood (1978) who provided a detailed summary for Heron Reef, that may be even further subdivided (Figure 4).

\section{Windward Reef Slope}

The reef slope is steeply inclined $\left(10-40^{\circ}\right)$ with two distinct terraces 4-6 m and 15-20 m (bmlw). The Reef Front Subzone is commonly covered with a profusion of staghorn coral, patches of platy forms on ledges and domal massive corals on the upper terrace and at the top of the slope. In places spur-and-groove structures are well developed. Exposed during low spring tides, the upper surfaces of spurs, support luxuriant low-profile growths of Acropora spp. and massive corals, whereas the growing edges and the terrace support branching and platy forms. Large, massive, domal corals are found on the fronts of spurs and on the terrace onto which the grooves open. Sandy gravel groove floors are devoid of coral growth. Corals decrease markedly below -10 m, and the Lower Reef Slope Subzone is a coral veneered cemented limestone mass with fans of coral debris, sloping gently down to the shelf floor. On the eastern margin, the reef slope flattens out at $-15 \mathrm{~m}$ onto the shallow platform between Heron and Sykes reefs.

\section{Reef Rim}

The reef rim is the highest part of the reef top being up to $10 \mathrm{~cm}$ above reef flat coral growth, and $60 \mathrm{~cm}$ above the lowest spring tide level. It is continuous around the perimeter of the reef except for gaps along the western tip and northeastern section. It slopes gently seaward and is irregularly terraced. Three subzones are typically recognizable and variously developed around the reef:

1. The outer Coralgal Subzone faces the oncoming breaking waves

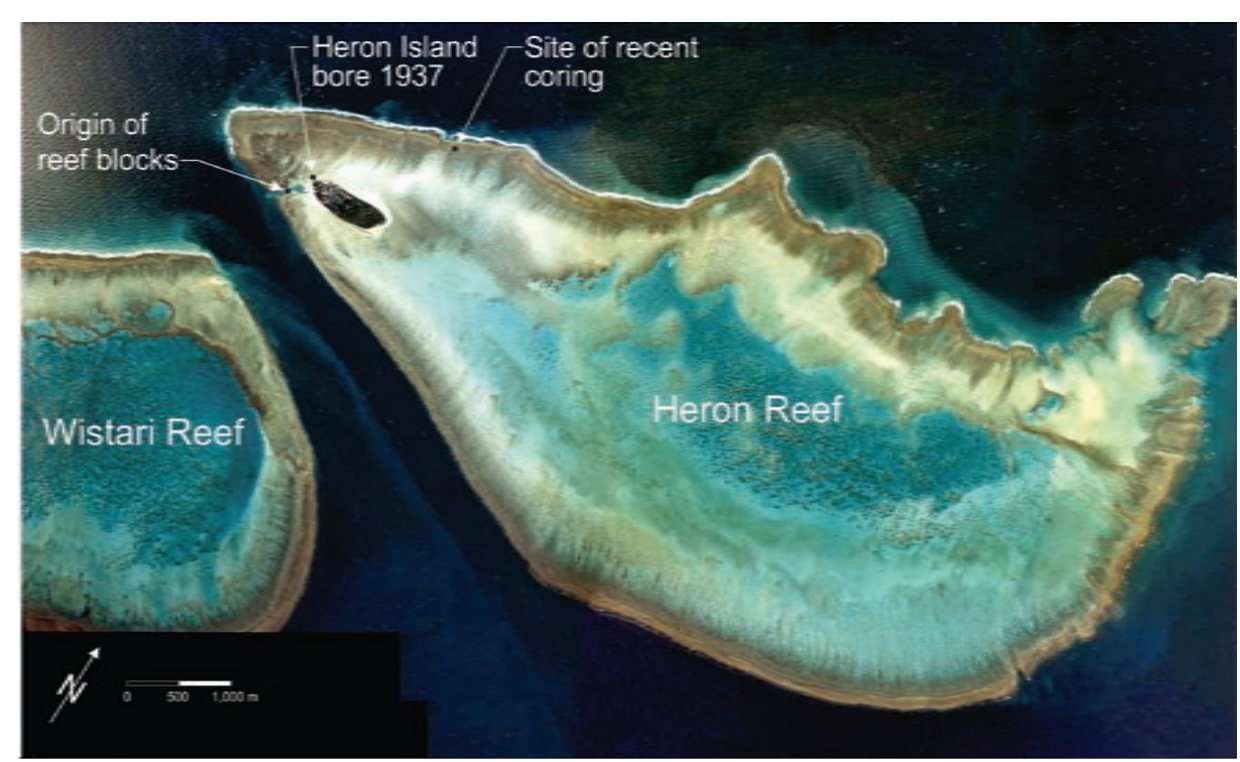

Figure 3 Composite aerial photograph of Heron Island and surrounding reef, showing zonation and position of boreholes and source of reef blocks. 


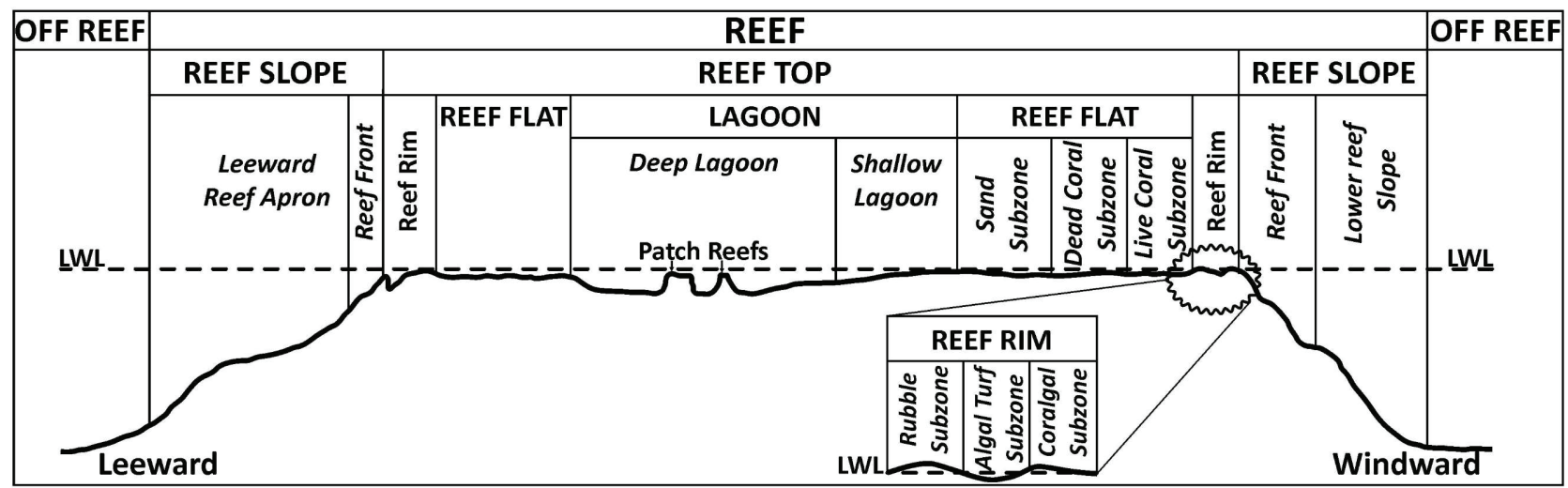

Figure 4 Generalised cross-section of a lagoonal platform reef such as Heron Reef showing the recognisable zones and subzones.

and is a smooth terraced pavement consisting of low profile corals heavily encrusted by coralline algae. The pavement is crossed by narrow runoff channels, and broken by sand floored pools rimmed with luxuriant coral growth. Rhodoliths occur in small pools.

2. The Algal Turf Subzone is a slightly lower area of the pavement encrusted by a mat of algae and some domal corals growing in its deeper parts. It has been referred to as the outer moat.

3. The Rubble Subzone is the highest varying from only a few to tens of metres wide and from thin sheets $10 \mathrm{~cm}$ thick to $1.5 \mathrm{~m}$ rubble banks. Extensive tongue-like shingle banks, at right angles to the eastern and southeastern margins, are common. Other banks occur W of the harbour entrance and W of Blue Pools NE of the cay. Rubble varies from Acropora shingle $(5 \times 1 \times 1 \mathrm{~cm})$ to coral plates $(20 \times 10 \times 2) \mathrm{cm}$ to reef blocks $>2 \mathrm{~m}$ in diameter. This subzone's outer boundary parallels the reef edge representing the inner extent of transport of the largest blocks whereas the inner boundary is typically finger-like reflecting transport of finer material into slightly deeper water. Rubble in the tongues is usually encrusted with coralline algae and coral growth is restricted to small pools within the rubble.

The Reef Rim isolates reef top waters from open shelf waters for several hours each low tide with water dammed up to $50 \mathrm{~cm}$ above outside waters creating strong runoffs through any gaps in the rim and influencing sedimentation patterns. In several places both windward and leeward double rims are developed.

\section{Reef Flat}

The reef flat is exposed at low tide within the reef rim. Corals grow to the level of the dammed water and are commonly heavily encrusted by coralline algae. The encrusted surface provides a very level surface. Four subzones are:

1. The Outer Living Coral Subzone has $>50 \%$ coral cover with more living than dead displaying a radial pattern perpendicular to the reef edge with coral pools and channels up to $80 \mathrm{~cm}$ deep. Its outer boundary is difficult to distinguish because of areas of coral growth on reefal substrate and growth of corals and coralline algae on tongues of rubble extending from the rubble subzone. This subzone has the highest density and diversity of corals.

2. The Dead Coral Subzone has similar coral coverage, but dead predominate over live corals and fleshy increase over coralline algae. It also becomes shallower and coral diversity decreases dramatically.

3. The Sand Subzone has $<50 \%$ coral cover, rare microatolls and bioturbation is extensive.

4. In places an Inner Coral Subzone is marginal to the lagoon, e.g., off the NE end of the cay. It has slightly deeper water and c. $50 \%$ coral cover with Halimeda and fleshy algae common.

\section{Lagoon}

The central lagoonal zone is a complex system of varying water depths and patch reefs. Two subzones (Smith et al., 1998) are:

1. The Deep Lagoon is 3-3.5 m (bmlw) with numerous 6$25 \mathrm{~m}$ patch reefs predominantly in the $\mathrm{N}$ and $\mathrm{E}$ where they occupy up to $50 \%$ of the surface. Patch reefs are mainly reefal limestone encrusted by coralline algae with scattered corals, Halimeda and fleshy algae. They supported much more coral growth before late 1960's cyclones. The northeastern lagoon is isolated by an E-W ridge that was thought to be a relic coral-algae ridge, but recent inspection in two areas indicates a thin rib of rubble. In the NW the deep lagoon is divided by an offshoot of the shallow lagoon. The fine lagoonal sediment contains a rich infauna and extreme bioturbation.

2. The Shallow Lagoon is typically $1 \mathrm{~m}$ deep and separated abruptly from the Deep Lagoon. It can be further subdivided into areas with and without sporadic coral growth. The former may represent coral growth on recently buried patch reefs. After calm weather the sediment surface is commonly blanketed with a yellow-brown cyanobacterial mat.

\section{Leeward Reef Slope}

The leeward reef slope is typically gentler $\left(10-20^{\circ}\right)$ than the windward, except where strong currents sweep around the ends of the reef. Seismic profiles perpendicular to the reef edge show that the slope is formed by an accretionary wedge of reefal sediment abutting the reef as the Reef Apron Subzone. The Reef Front Subzone extends as tongues from the reef rim on top of the Apron and may have spur-and-groove appearance. Massive Porites heads several metres in diameter and other patches of coral growth are common in water to $-10 \mathrm{~m}$. The apron may extend $0.5 \mathrm{~km}$ from the reef edge. Ryan et al. (2001) detailed the sediment apron to the lee of Wistari Reef. 


\section{Reefal Shoal}

The platform between Heron and Sykes is in waters 10-14 m deep with large sand dunes migrating over its undulating surface. Large stands of corals including Acropora form small reefal patches along the platform edge (see Jell and Flood, 1978).

\section{Sand Cay}

The sand cay rises abruptly from the southern beach to a height of $4.5 \mathrm{~m}$ (mhwl) and slopes gently to the $\mathrm{N}$. The beach is $10-25 \mathrm{~m}$ wide and bordered by beachrock in a 9-20 $\mathrm{m}$ wide belt from $\mathrm{E}$ of the harbour to past the eastern end of the island. Its strike parallels that of the beach and dips seaward at $2-12^{\circ}$, decreasing seaward. The beachrock is bordered by a $50 \mathrm{~cm}$ deep moat. The moat is caused by wave scour. Strong tidal currents channel along the moat to and from the harbour adding to the scour. The moat is populated sparsely by molluscs and a few corals including Porites lutea that rolls around the moat with the coral living on the part of the colony that is uppermost at the time.

Shark Bay, at the eastern end, is a wide beach accreting to the NE. The flat area above the beach is favourable for nesting turtles and they significantly disturb the sediment. A wide tear-drop shaped sand bank off the NE beach displays tidal sedimentary structures and is strongly bioturbated. Several generations of beachrock crop out around the NW end of the Island which is being eroded since the harbour was installed to the extent that cement walls are necessary to protect the Resort.

\section{Sediments}

Maxwell (1968) provided a comprehensive regional study of GBRP sedimentology. Mathews et al. (2007) reviewed the next 40 years of studies providing an up-to-date synthesis. Maxwell and Maiklem (1964), and Maiklem (1970) investigated the inter-reef sediments of the Capricorn/Bunker groups. Maxwell et al. (1961, 1964) described the Heron Reef reef-top sediments. Sediments of the reef slope have not been studied.

\section{Shelf sediments}

The continental shelf sediments are influenced by their mainland provenance, a submarine dune source, a reefal source, and in situ benthic foraminifers, bryozoans and molluscs. Three facies (Jell and Flood, 1978, text-fig. 13) are:

1. Terrigenous: $<60 \%$ carbonate, inner shelf adjacent to the mainland, detrital quartz sand a major constituent derived from coastal dunes and ancient dune systems of the shelf and older fluviatile deposits.

2. Carbonate: $>80 \%$ carbonate, on the outer shelf around the reefs, reef-derived bioclastic carbonate sand and gravel, in situ benthic foraminifers, bryozoans, molluscs, Halimeda, etc. A low-mud subfacies is restricted to the immediate proximity of the reefs, and consists of moderately sorted carbonate sand and shingle (i.e. coral sticks of gravel size or coarser). A variable mud subfacies consists of poorly sorted carbonate sand, and it represents the area free of coarse-grained reef derived skeletal debris.

3. Mixed (or transitional): $60-80 \%$ carbonate, transitional between the other two facies.

\section{Reef sediments}

Maxwell et al. (1964) showed that corals, coralline algae, foraminifers, molluscs and Halimeda account for c. $90 \%$ of reef top sediment. A range of factors influence particle size and degree of sorting. Coralline algae (calcitic), which are relatively resistant to mechanical break-down, contribute to coarse sands and gravels on the reef rim. Corals (aragonitic) break down rapidly into distinct size modes (shingle sticks and very coarse, fine to very fine sand). Winnowing by breaking waves and translatory waves leaves boulder and gravel particles as a lag deposit (Rubble Subzone) on the reef rim and outer reef flat, and transports coarse sand into the Sand Subzone and Shallow Lagoon. Very fine sand and silt are carried in suspension to the Deep Lagoon where it settles during periods of slack water, or off the reef onto the continental shelf. Consequently, there is a generally fining size gradient from windward reef rim to central lagoon. Factors differentiating particle size also promote segregation of calcitic detritus (coralline algae and foraminifers) as coarser sediments, remaining near source from aragonitic detritus (corals and Halimeda) as finer material transported towards the lagoon. This concentric pattern is modified by tidal currents. Sediment thickness varies from very thin on the Reef Flat, $<10 \mathrm{~cm}$, to $4 \mathrm{~m}$ below the Shallow Lagoon and $>5 \mathrm{~m}$ in the Deep Lagoon (Smith et al., 1998).

\section{Internal architecture}

The 1937 Heron Island bore provided no reliable dates and little data on the internal structure of the reef.

\section{Shallow cores}

Cores from within $20 \mathrm{~m}$ of the western reef margin to the NE of the cay (Nothdurft et al., 2010) call into question the 'classical' reef model of Marshall and Davies (1982). U-series dates of the cores are 7.3-4.2 ka with the reef flat having reached its current elevation $5.4 \mathrm{ka}$ at the innermost position and $4.2 \mathrm{ka} 20 \mathrm{~m}$ towards the margin. Hence, the leeward reef reached sea level relatively early and prograded c. $20 \mathrm{~m}$ at current sea level in c. $1 \mathrm{ka}$. A single core, $25 \mathrm{~m}$ inward from the windward reef near the cay dated at $1.9 \mathrm{ka}$ at $0.1 \mathrm{~m}$ and $3.0 \mathrm{ka}$ at $0.7 \mathrm{~m}$ depths, suggesting much more significant progradation on the windward margin at the channel between Heron and Wistari reefs than on the opposing leeward margin. Greater windward progradation may account for the wider windward reef flat relative to the lee.

\section{Reefrock blocks}

Blocks of shallow (upper 2-3 m) reefrock were dredged to enlarge the boat harbour in 1988. Three large blocks (dimensions 0.5-1.2 m) and c. 30 smaller blocks were collected and many more remain in retaining walls on Heron Island. The three large blocks contain corals in growth position and their upper surfaces had been the top floor of the reef flat. They were sawn into $20 \mathrm{~cm}$-thick slabs and cut surfaces were logged for constituents and macro-porosity using a $5 \mathrm{~cm}$ grid. Selected microbialite crusts and skeletal substrates were dated by ${ }^{14} \mathrm{C}$ accelerator mass spectrometry (AMS) (Webb and Jell, 2006). Although the samples may not be a statistically valid subset of the overall reef framework or volume, they are a representative set, 

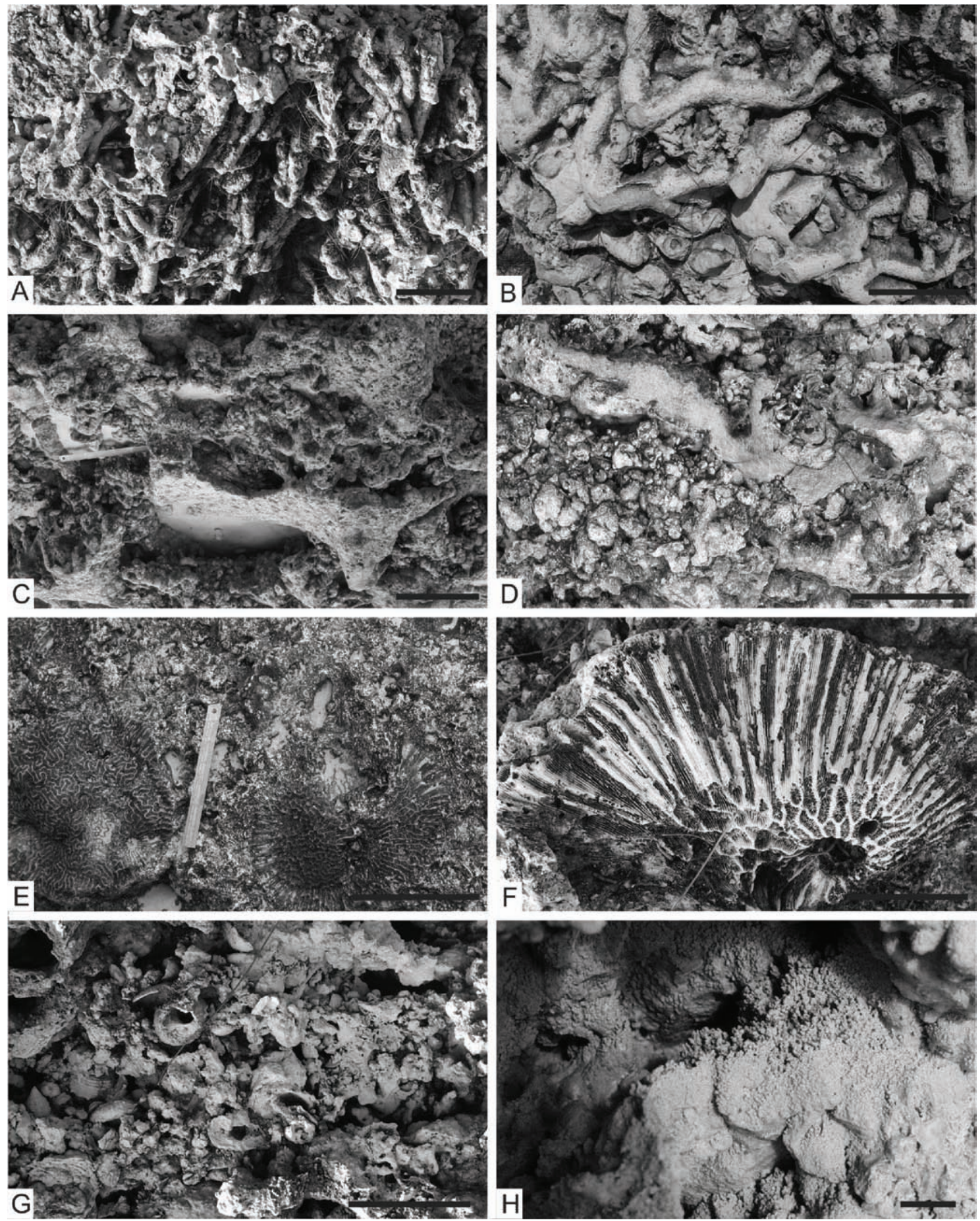

Figure 5 Reef blocks, Heron Island boat channel. Scale bars $=15 \mathrm{~cm}$ (except as noted). A). Branching Acropora framework with thick coralline algal crusts and microbialite, but little entrapped rubble. B). Underside of branching Acropora framework with some entrapped rubble. $C$ ). A. hyacinthus complex framework with large laterally contiguous cavity system. D). A. hyacinthus complex framework with abundant coarse rubble bound into extensive cavity system. E). Massive coral facies. F). Massive coral facies - Goniastraea sp. Scale bar= $5 \mathrm{~cm} . \mathrm{G})$. Stratified rubble bound by microbialites. Scale bar $=10 \mathrm{~cm} . \mathrm{H}$ ). Thrombolitic microbialites in framework cavity. Scale bar $=2 \mathrm{~cm}$. 
indicative of the relative percentages of coral, algae, rubble, microbialite and cavity in average well-lithified reefrock in the vicinity of the boat harbor.

The reefrock blocks are generally well lithified with abundant open porosity and consist of varying mixtures of in situ (i.e., growth position) corals and encrusting organisms (e.g., coralline algae, foraminifers), coarse debris, and microbialite. Any unconsolidated sediment originally within cavities had been removed, presumably during dredging. Individual coral frameworks in the blocks include (1) branching acroporids (Figure 5A, B), 2) overlapping vase- to tableshaped acroporids (e.g., A. hyacinthus group) (Figure 5C, D), and (3) massive corals (Figure 5E, F). Coarse rubble fills the bases of some growth cavities, but dominates rare blocks in laterally continuous strata (Figure 5G). Although coralline algae are important binders in these framework blocks, coarse debris was bound primarily by microbialite, which is a conspicuous component within most observed cavity systems (Figure 5H).

The three quantified blocks represent two major types of reef framework and composition data are shown in Table 1. Two of the blocks consist primarily of in situ corals (21-26\% volume) dominated by $A$. hyacinthus group corals with subordinate branching acroporids, rare massive and encrusting corals, scattered coarse debris (5-9\% volume), and a large laterally connected cavity system (30-36\% volume). Cavities $>10 \mathrm{~cm}$ in diameter are common and are generally better connected laterally than vertically owing to the overlapping plate-like coral habit. Similar A. hyacinthus group and staghorn acroporids dominate coral taxa in shallow reef slope environments near the harbor. The third block contains more lithified coarse debris (18\%), mainly in pockets within a growth framework constructed by more scattered branching and plate-like corals ( $7 \%$ volume). The cavity system in the debris-rich framework is more irregular, with smaller dimensions, but accounts for $39 \%$ by volume. Coralline algae are volumetrically important in all blocks (15-17\%), and microbialites that preferentially line the lower surfaces and walls of cavities (Figure $5 \mathrm{H})$ make up $6-8 \%$ by volume.

Frameworks with in situ corals dominate the assemblage. Blocks with branching coral frameworks generally contain the least bound coarse debris and contain very open cavity systems between horizontal ledges made up of wedged debris and or encrusting corals. Acropora hyacinthus frameworks contain rare or abundant coarse debris and massive corals, which are less abundant within the blocks, are commonly associated with more abundant coarse debris (Figure 5D). Blocks dominated by coarse debris are rare, but potential bias exists

Table 1 Volumetric percentages of components based on point counts of reefrock fabric in three excavated blocks from reef flat, harbour channel, Heron Reef.

\begin{tabular}{lrrrr}
\hline Heron Reefrock & \multicolumn{3}{c}{ Percentage on slab } & \\
\cline { 2 - 4 } Block component & Block 1 & Block 2 & Block 3 & Total \\
\hline Coral in growth position & 21.2 & 7.2 & 26.3 & 17.2 \\
Red algae crust & 17.5 & 14.9 & 15.1 & 15.9 \\
Coarse debris & 9.4 & 17.6 & 4.6 & 11.3 \\
Vermetid gastropod & 0.5 & 0.0 & 0.0 & 0.2 \\
Encrusting foraminifer & 0.9 & 0.9 & 2.0 & 1.2 \\
Microbialite & 8.5 & 6.3 & 6.6 & 7.2 \\
Framework cavity & 30.2 & 38.7 & 35.5 & 34.8 \\
Boring in skeleton/debris & 11.8 & 14.4 & 9.9 & 12.3 \\
\hline
\end{tabular}

$n=586$ wherein in situ growth frameworks may be more easily preserved as large blocks than debris accumulations. The more open cavity systems of growth framework may have been more conducive to unification by microbialites, but coarse debris also hosts significant cavity systems and microbialites played a very significant role in unifying the well lithified debris-rich blocks. Contrary to some other reef environments, in situ coral framework is an abundant part of the reefrock on the western end of Heron Reef.

Skeletal substrates date at 6610-6050 yrs BP (uncorrected ages) (Webb and Jell, 2006). Microbialite growth began in enclosed framework cavities within c. 200-300 years of the substrates (corals) having been alive and then accreted at 28-34 $\mu \mathrm{m} / \mathrm{yr}$ (mean $=29 \mu \mathrm{m} /$ $\mathrm{yr}$ or $2.9 \mathrm{~mm} / 100 \mathrm{yr}$ ). Microbialites grew for 228-319 years (Webb and Jell, 2006). Hence, microbialites were emplaced relatively soon (i.e., <300 years) after death of the skeletal substrates as the framework accreted, and microbialite growth continued for only a few hundred years once established. A similar pattern of growth was found in Tahitian microbialites (Seard et al., 2011). As microbialites were not significantly affected by subsequent cementation after they stopped growing (Webb et al., 1998), their role in framework binding is best considered the final, but integral, phase of framework growth rather than a subsequent diagenetic lithification event.

\section{Conclusions}

Heron Reef is an excellent example of a lagoonal platform reef developed on a partially rimmed platform in a high energy environment with continued water turnover due to high tidal flows and clear access to open ocean. All geomorphological units are easily recognizable and the sedimentology is well known. The 1937 Heron Island bore penetrated the complete though thin (c. $150 \mathrm{~m}$ ) reef and showed that Holocene growth was c. $15 \mathrm{~m}$, but additional coring is required to gain further information on its age of initiation, Pleistocene structure and complete developmental history. The Holocene/ Pleistocene unconformity has been geophysically identified under the full length of Heron Reef across the shoal area to beneath Sykes Reef. However, more sensitive equipment is needed to obtain details of the topography of the antecedent platform to assess its possible influence on the morphology of the reef. Rare cores through the Holocene suggest that its development does not fit the 'classical' model. Large reef blocks reveal the fabric of the upper part of the Holocene reef and suggest that abundant in situ coral framework occurs in the shallow reef rock, that microbialites were important in the final unification stage of framework development and that lithified rubble occurs but is relatively rare.

\section{Acknowledgements}

We thank Alexander Jell for help with figures, and David Hopley and Jody Webster for constructive reviews.

\section{References}

Abbey, E., Webster, J.M. and Beaman, R.J., 2011, Geomorphology of submerged reefs on the shelf edge of the Great Barrier Reef: The influence of oscillating Pleistocene sea-levels: Marine Geology, v. 288, pp. 61-78.

Beaman, R.J., Webster, J.M. and Wust, R.A.J., 2008, New evidence for drowned shelf edge reefs in the Great Barrier Reef: Marine Geology, v. 247, pp. 17-34. 
Blanchon, P., Jones, B. and Kalbfleisch, W., 1997, Anatomy of a fringing reef around Grand Cayman: storm rubble, not coral framework: Journal of Sedimentary Research, v. 67, pp. 1-16.

Braithwaite, C.J.R. and Montaggioni, L.F., 2009, The Great Barrier Reef: a 700000 year diagenetic history: Sedimentology, v. 56, pp. 15911622 .

Braithwaite, C.J.R., Dalmasso, H., Gilmour, M.A., Harkness, D.G., Henderson, G.M., Kay, R.L.F., Kroon, D., Montaggioni, L.F. and Wilson, P.A., 2004, The Great Barrier Reef: the chronological record from a new borehole: Journal of Sedimentary Research, v. 74, pp. 298-310.

Brandon, D.E., 1973, Waters of the Great Barrier Reef Province, in Jones, O.A. and Endean, R. (eds), Biology and geology of coral reefs. 1. Geology, 1: Academic Press, New York, pp. 187-232.

Davies, P.J., 1974, Subsurface solution unconformities at Heron Island, Great Barrier Reef: $2^{\text {nd }}$ International Coral Reef Symposium, Proceedings, v. 2, pp. 573-578.

Davies, P.J., 2011, Great Barrier reef: origin, evolution, and modern development, in Hopley, D. (ed), Encyclopedia of modern coral reefs: structure, form and process: Springer, Dordrecht, pp. 504-534.

Davies, P.J. and Hopley, D., 1983, Growth facies and growth rates of Holocene reefs in the Great Barrier Reef: BMR Journal of Australian Geology and Geophysics, v. 8, pp. 237-252.

Davies, P.J. and McKenzie, J.A., 1993, Controls on the Pliocene-Pleistocene evolution of the northeastern Australian continental margin: Proceedings of the Ocean Drilling Program, Scientific Results, v. 133, pp.755-762.

Davies, P.J. and Peerdeman, F.M., 1998, The origin of the Great Barrier Reef - the impact of Leg 133 drilling: International Association of Sedimentologists, Special Publication, no. 25, pp. 23-38.

Davies, P.J., Symonds, P.A., Feary, D.A. and Pigram, C.J., 1988, Facies models in exploration - the carbonate platforms of north-east Australia: APEA Journal, v.28, pp. 123-143.

Davies, P.J., Braga, J.C., Lund, M. and Webster, J.M., 2004, Holocene deep water algal buildups on the eastern Australian shelf: Palaios, v. 19, pp. 598-609.

Dubois, N., Kindler, P., Spezzaferri, S. and Coric, S., 2008, The initiation of the southern central Great Barrier Reef: New multiproxy data from Pleistocene distal sediments from the Marion Plateau (NE Australia): Marine Geology, v. 250, pp. 223-233.

Fairbridge, R.W., 1950, Recent and Pleistocene coral reefs of Australia: Journal of Geology, v. 58, pp. 330-401.

Flood, P.G., 1993, Geological history of the reef, in Mather, P. and Bennett, I. (eds), A coral reef handbook: Surrey Beatty and Sons, Sydney, pp. 3-6.

Flood, P.G. and Jell, J.S., 1977, The effect of cyclone "David" (January, 1976) on the sediment distribution patterns on Heron Reef, Great Barrier Reef, Australia: Third International Coral Reef Symposium, Miami, Proceedings, v. 2, pp. 119-126.

Harvey, N., 1986, The Great Barrier Reef: Shallow seismic investigations: Geography Department, James Cook University, Monograph Series, no. 14, $103 \mathrm{pp}$.

Hopley, D., 1982, The geomorphology of the Great Barrier Reef: Quaternary development of coral reefs: John Wiley, New York, 451 pp.

Hopley, D., Smithers, S.G. and Parnell, K.E., 2007, The geomorphology of the Great Barrier Reef: development, diversity, and change: Cambridge University Press, Cambridge, 532 pp.

Hubbard, D.K., Miller, A.I. and Scaturo, D., 1990, Production and cycling of calcium carbonate in a shelf-edge reef system (St. Croix, U.S. Virgin Islands): Applications to the nature of reef systems in the fossil record: Journal of Sedimentary Petrology, v. 60, pp. 335-360.

Hubbard, D.K., Gill, I.P. and Burke, R.B., 2001, The role of framework in modern reefs and its application to ancient systems, in Stanley, G.D., Jr. (ed), The history and sedimentology of ancient reef systems: Kluwer Academic, pp. 351-386.

Jell, J.S. and Flood, P.G., 1978, Guide to the geology of reefs of the Capricorn and Bunker groups, Great Barrier Reef Province, with special reference to Heron Reef: Department of Geology, University of Queensland, Papers, v. 8 , pp. $1-85$.
Maiklem, W.R., 1968, The Capricorn reef complex, Great Barrier Reef, Australia: Journal of Sedimentary Petrology, v. 38, pp. 785-798.

Maiklem, W.R., 1970, Carbonate sediments of the Capricorn reef complex, Great Barrier Reef, Australia: Journal of Sedimentary Petrology, v. 40, pp. $55-80$

Marshall, J.F., 1977, Marine geology of the Capricorn Channel area: Bureau of Mineral Resources, Geology and Geophysics, Bulletin, v. 163.

Marshall, J.F., 1983, The Pleistocene foundations of the Great Barrier Reef, in Baker, J.T., Carter, R.M., Sammarro, P.W., and Stark, K.P. (eds), Proceedings of the Great Barrier Reef Conference: James Cook University, Townsville, pp. 123-128.

Marshall, J.F. and Davies, P.J., 1982, Internal structure and Holocene evolution of One Tree Reef, southern Great Barrier Reef: Coral Reefs, v. 1, pp. 2128.

Mathews, E.J., Heap, A.D. and Woods, M., 2007, Inter-reefal seabed sediments and geomorphology of the Great Barrier Reef, a spatial analysis: Geoscience Australia, Record, 2007/09, 140 pp.

Maxwell, W.G.H., 1968, Atlas of the Great Barrier Reef: Elsevier, Amsterdam.

Maxwell, W.G.H., 1969, Physical geography and oceanography, in The future of the Great Barrier Reef: Australian Conservation Foundation, Special Publication, no. 3, pp. 5-14.

Maxwell, W.G.H. and Maiklem, W.R., 1964, Lithofacies analysis, southern part of the Great Barrier Reef: Department of Geology, University of Queensland, Papers, v. 5, pp. 1-21.

Maxwell, W.G.H., Day, R.W. and Fleming, P.J.G., 1961, Carbonate sedimentation on Heron Island Reef, Great Barrier Reef: Journal of Sedimentary Petrology, v. 31, pp. 215-230.

Maxwell, W.G.H., Jell, J.S. and McKellar, R.G., 1964, Differentiation of carbonate sediments on the Heron Island Reef: Journal of Sedimentary Petrology, v. 34, pp. 294-308.

Montaggioni, L.F., 2005, History of Indo-Pacific coral reef systems since the last glaciations: Development patterns and controlling factors: Earth Science Reviews, v. 71, pp. 1-75.

Montaggioni L.F. and Braithwaite, C.J.R., 2009, Quaternary coral reef systems: history, development processes and controlling factors: Elsevier, Amsterdam, 532 pp.

Northdurft, L.D., Webb, G.E., Opdyke, B.N., Price, G.J. and Zhao, J.-x., 2010, Keep up, catch up or give up: implications of shallow transect coring, Heron Reef, Great Barrier Reef, Australia: 2010 Australian Earth Sciences Convention (AESC), Geological Society of Australia, 4-8 July, National Convention Centre, Canberra, Australian Capital Territory, Abstracts, pp. 231-232.

Richards, H.C. and Hill, D., 1942. Great Barrier Reef bores, 1926 and 1937 : Report of the Great Barrier Reef Committee, v. 5, pp. 1-111.

Rieg1, B., 2001, Inhibition of reef framework by frequent disturbance: examples from the Arabian Gulf, South Africa, and the Cayman Islands: Palaeogeography, Palaeoclimatology, Palaeoecology, v. 175, pp. 79-101.

Ryan, D.A., Opdyke, B.N. and Jell, J.S., 2001, Holocene sediments of Wistari Reef: towards a global quantification of coral reef related neritic sedimentation in the Holocene: Palaeogeography, Palaeoclimatology, Palaeoecology, v. 175, pp. 173-184.

Seard, C., Camoin, G., Yokoyama, Y., Matsuzaki, H., Durand, N., Bard, E., Sepulcre, S., and Deschamps, P., 2011, Microbialite development patterns in the last deglacial reefs from Tahiti (French Polynesia; IODP Expedition \#310): Implications on reef framework architecture: Marine Geology, v. 279 , pp. $63-86$.

Smith, B.T., Frankel, E. and Jell, J.S., 1998, Lagoonal sedimentation and reef development on Heron Reef, southern Great Barrier Reef Province: International Association of Sedimentologists, Special Publication, v. 25, pp.281-294.

Symonds, P.A., Davies, P.J. and Parisi, A. 1983, Structure and stratigraphy of the Great Barrier Reef: BMR Journal of Australian Geology and Geophysics, v. 8, pp. 277-291.

Veeh, H.H. and Veevers, J.J., 1970, Sea level at -175 m off the Great Barrier Reef: Nature, v. 226, pp. 536-537.

Webb, G.E. and Jell, J.S., 2006, Growth rate of Holocene reefal microbialites 
- implications for use as environmental proxies, Heron Reef southern Great Barrier Reef: Australian Earth Science Convention, Melbourne, 2-6 July, Extended Abstracts, Searchable Compact Disc (ISBN 0-64646265-2), doi:10.1071/ ASEG2006ab191.

Webb, G.E., Baker, J. C. and Jell, J. S., 1998, Inferred syngenetic textural evolution in Holocene cryptic reefal microbialites, Heron Reef, Great
Barrier Reef, Australia: Geology, v. 26, pp. 355-358.

Wolanski, E., 1994, Physical oceanographic processes of the Great Barrier Reef: CRC Press, Boca Raton, 194 pp.

Yokoyama, Y., Purcell, A., Marshall, J.F. and Lambeck, K., 2006, Sea-level during the early deglaciation period in the Great Barrier Reef, Australia: Global and Planetary Change, v. 53, pp. 147-153.

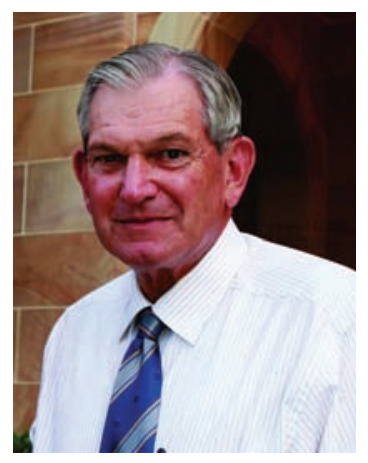

John S. Jell is the former head of the Department of Earth Sciences, University of Queensland. He has been leading field excursions to Heron Island for over 40 years. He is a palaeontologist/stratigrapher with interest in corals and coral reefs, especially in the Silurian and Devonian, and has found his research on the Great Barrier Reef of great benefit in interpreting ancient forms, and vice-versa, especially in the renowned Devonian Canning Basin

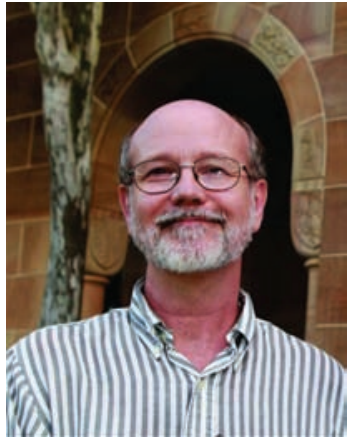

Gregory E. Webb is the Dorothy Hill Professor of Palaeontology and Stratigraphy at the University of Queensland. He specialises in modern and ancient corals, reefs and microbialites, with a major emphasis on the geochemistry and reef-building role of microbialites through time. Recently, he has been investigating reef framework development on Heron Reef, along with coral biomineralisation and early diagenesis. 